\title{
The presence of critical thinking in the altiplano Peruvian
}

\author{
Vicente Alanoca Arocutipa
}

\begin{abstract}
The development of critical thinking in the context of the social sciences, has its bases in Europe, today it is known as critical theory, is an important reference, not only for Europe but for the social sciences in the world. In that act came from Latin America some intellectuals who are now leaders in the development of critical thinking. Therefore the goal is visible from the daily life of the plateau critical thinking, where the academy has decontextualized and disconnected from reality but the Quechua and Aymara people in the historical process known face and embody the great social problems facing peoples, despite limitations and stigmatization they have developed daring thoughts of hope against the social and environmental collapse, which some would call it common thoughts. Faced with these ways of dealing with the crisis, conservative thought, has not yet been cataloged or give a nomenclature from sociology, anthropology, education, philosophy, political science, economics, etc., because their roots, theoretical and methodological are anchored in Europe, North America and Asia, which confirm and universities legitimizing these recipes. This does not mean rejecting Western European knowledge but is to debate how is that even other forms of thought and action are recreated from the Andes. Despite adversity it must be retaken for the decolonization of knowledge and bet on respect for human dignity.
\end{abstract}

Keywords- critical, emancipation, thinking, Peru,Altiplano.

\section{INTRODUCTION}

social sciences in debate and their implication in critical thinking

In the process of the development of universal knowledge, it is known that the social sciences have taken epistemological bases of the natural sciences, this situation has led to a deterministic interpretation of the social world with the implantation of positivism. Morin, as an important question, induces us on it, "it is necessary first of all to become aware of the nature and consequences of the paradigms that mutilate knowledge and disfigure the real" (Morin 2001, 29). On the other hand, in the scenario of Western culture, Husserl, the following question was posed: "Can one speak seriously of a crisis in our sciences? The crisis of a science, however, means nothing less than the following: its authentic scientific character, the whole form in which it raises its task and the method it constructs for it, have become questionable "(Husserl 2008, 47). These issues were not taken into account in addressing the disciplines of the social sciences in many academic areas of the Latin American countries, for whom they have concentrated the power of knowledge under the rubric of positivist science, "we know that throughout Of the history of this world system colored peoples were subjected to a formal colonization, as well as to slavery. We know that there are many forms of formal discrimination that affect population transfers "(Wallertstein 2007, 237).

The development of the social sciences in Peru from the academy is anchored under parameters of a positivist overlapping eurocentric that left aside all the possibility of criticism, despite the fact that in the contemporary world researchers, intellectuals, scholars and thinkers have emerged in diverse Contexts such as in Asia, Africa, Europe, North America and Latin America, who are facing and embodying the great problems facing mankind, which the academy, especially since the discipline of anthropology, has shunned and fallen into a kind of mutis since The schools of anthropology. Despite the fact that "although critical anthropologists try to make injustice and exploitation a new starting point, supplanting the false pretensions of politically or positivist and neutral approaches" (Harris 2000, 61), the issue Is to visualize other existing forms of thinking that contain alternative elements in the face of social and environmental collapse. In the framework of approach they find and rediscover other forms of thinking that positivism has silenced and excluded from the different disciplines of social sciences cloistered in the Eurocentrism that today faces serious problems in its perspectives, methodologies, especially in the interpretation and the Resolution of social problems such as corruption, exclusion, insecurity, drug addiction, alcoholism, prostitution, among other evils.

In this context, the present article "the presence of critical thinking in the Peruvian highlands" aims to visualize the process of reflection that has been instituted in relation to the social sciences from the different actors of the academy, thinkers and intellectuals, activists and Leaders, who have contributed in the table of the debate and to operate from the quarry of the Andes. For methodological questions the content of the present is divided into three parts, in the first point addresses the development and 
debate of critical thinking from the social sciences; In the second part, we discuss the recreation of thought from the emancipatory space and in the third point we develop the importance of thinking from the highland context, above all we try to link from the everyday, that is from the spaces of struggle.

In the last part we tried to present some specific conclusions that could help us to think and act differently from everyday life in order to avoid falling into andinocentrismo. For the development of the present work we identify two scenarios as support, one of them is the bibliographical and on the other hand the daily life; Where we see the indignation that shows the population, especially in Puno.

It is not a finished work, nor much less a guide to question the state of things present in society today, but rather, seeks to assume in the ballast of indignation winks of hope, above all giving importance to the struggle undertaken since the Everyday life from the context of the plateau and considering education as the axis of transformation of the country of all the blood.

\section{The development of critical thinking from the social sciences in the Peruvian highlands}

Talking about the social sciences in present-day Peru, especially from the Peruvian highlands, may even mean for Lima's centralism, unacceptable and outdated passion for "ignorant", "radical", "essentialist", "intolerant" people among other stigmatizing categories Which de-legitimizes any possibility of creativity from the Andes in the face of the great problems facing humanity today. There are certain fundamental elements that require us in the personal and above all, "the intellectual has to start from the critic, to put" the finger to sore "by pointing out the discomfort that (re) produces a social situation" (Portocarrero 2015, 13). However, there are those who had as recreation space of thought the highlands, although some were casting cologne to not feel the pain and suffering of the Quechua and Aymara peoples. On the other hand, it is pertinent to find daring thoughts of the "social scientists" who have been questioning since the end of the 20th century and the beginning of the XXI century, because "Western modern thought advances by operating on the abysmal lines that divide from human to subhuman So that human principles are not compromised with inhuman practices (Santos 2010,36).

In the process of reflection and debate, it is necessary to examine and contextualize critical thinking from the shores of Lake Titicaca, in contrast to what happens in Peru, as in other societies called postcolonial, diverse worlds coexist, simultaneously Face, mix, and ignore "(Portocarrero 2013, 10). It is known that the classical view of science that prevailed several centuries ago, was built on two premises. One was the Newtonian model in which there is a symmetry between the past and the future. It was an almost theological vision. The second premise "was the Cartesian dualism, the assumption that there is a fundamental distinction between matter and mind between the physical world and the social and spiritual world" (Wallerstein 2006, 4). This situation for some professionals in the social sciences has not yet been overcome, it is worse in contexts "where political leaders are controlled by mestizos" (Alanoca 2011, 219), here we can identify some academics in the highlands with those characteristics and profiles.

In this context it is necessary and evident to break down critical thinking, according to Facione, are "critical thinking skills, these are classified as cognitive skills and dispositions. Cognitive abilities, considered as the essential of critical thinking composed by: interpretation, analysis, evaluation, inference, explanation and selfregulation "(Facione, 2007). Each of these plays an important role in the process of critical thinking action. Consequently, the population in the highlands, as in any geopolitical space has generated knowledge and for the upbringing of life, "who have been claiming their territory, language and culture, including power" (Alanoca 2012, 103) Wisdom and knowledge, despite the atrocities of savage capitalism remain in force.

History shows us the institutionalization of the social sciences during the nineteenth century in five countries, such as Great Britain, France, Germany, Italy and the United States, which until today are cataloged and achieved international prestige, from which works were amassed for Different disciplines of the work of the social sciences in the world, Latin America, in our case in Peru. "The disciplines constitute a system of control in the production of discourse, fixing its limits through the action of an identity that takes the form of a permanent reactivation of the rules" (Foucault 1972, 224), in this logic and in the Framework of the social sciences in Latin America has been applied hegemonic recipes for the various disciplines where the teaching of different careers were taught and taught.

Without the spirit of ignorance and recognition of the contribution of the social sciences faculties of the Limean universities, they are still blind to the diverse and plural realities of the country of All Bloods, as Arguedas would maintain, a publication of this nature reads verbatim as : "It has focused on seeking academic excellence, broadening the knowledge of the disciplines that comprise it and applying various theories and methodologies to reflect on social reality that allow the formulation of appropriate policies and initiatives for Peru" (Fairlie, 9).It is not a matter of invalidating the contributions and reflections on the problems faced by the country, which 
the social sciences have an obligation to contribute to the solution, but, rather, these proposals are not only assumed as recipes to apply without doubts and murmurings in the Different spaces of public management as it is being applied. The great social problems facing the capital today, such as insecurity and corruption at all levels, from these atriums of academia the social sciences has not found the tip of the skein, which from our modest point of view, is a Socio-cultural situation, which also has to face socioculturally.

The existence of the centers from which political, social, economic, cultural and environmental decisions are generated, in the Peruvian case has always been and will continue to be the capital Lima. The reasons are obvious as it is the center of political power, which in the end is legitimate and necessary; But many of the decisions in practice are illegitimate for the Quechua, Aymara and Amazonian peoples of deep Peru, and are equally impertinent for the country's development process. Faced with such a situation from the same quarries of the periphery, what today is called critical thinking, rather than thinking logically or analytically, implies thinking rationally and objectively. Critical thinking is a process by which we use our knowledge and intelligence to reach the most reasonable and justifiable positions, requires us to identify obstacles to rational thinking, and also allows us to evaluate our way of thinking autonomously.

The department of Puno as a geopolitical space is not alien to the economic, social, political, ideological and cultural changes that crystallized at the end of the 20th century in the figure of "neoliberalism" where forms the ancestral ways of facing life go To suffer mutations, because the spaces that supposedly are built "knowledge", "culture", "civilization" and "science" were disconnected from everyday life. These spaces are the schools or the universities where only they are going to knead contents descontextualizados of the diverse disciplines or schools of professional formation.

Today the social sciences, especially in the Puno region, have not been shaken by their homogenizing and hegemonic character anchored in the overlapping Eurocentrism; We must not forget and be naive of the great problems facing the highland region as it is the subject of contamination of the sacred lake of the Incas such as Titicaca, the subject of anemia according to the data indicate us $82 \%$ of boys and girls They present this disease, that is to say every 10 infants 8 have that problem, the factors are several and above all it is structural. Another problem is that Puno has been stigmatized as a highly conflictive region, due to the constant protests and demands of the population that have been demanding in the different provinces and districts where the mining companies have been operating, which have been affecting the very experience of the population . They also "draw traumatic memories of past unhealed interstate conflicts and obsolete conceptions of national security" (Letamendia 2011, 28). To this we can add some facts of corruption where are committed authorities of the district, provincial and regional governments; Civil servants and civil servants, just as some of the justice system, prosecutors, judges, and police officers involved at the highest level are the evils that are currently being weighed against the high plateau.

The task of the social sciences in this context demands to leave that anchor or cloister, where education is not only and continues to be a test of knowledge transmission, on it and several teachers and leaders such as: Manuel $\mathrm{Z}$. Camacho, José Antonio Encinas, Maria Asunción Galindo, Telesforo Catacora, among others, gave us contributions to critical thinking, from the daily life of a teacher, which has little or no importance, one due to its provincial origin and so far from Lima, farther from Europe And the United States.

In the work of sociology in Puno we have stalled under the umbrella of Weberian thought and Marxism that have led us to a decontextualized political thought excluding, which has raised some ideologies decontextualized as was the political violence that faced Puno, in Particularly the northern provinces of Puno. In Anthropology we can not leave a culturalist contemplative anthropology, which often induces us to fall into the "andinocentrism" of traditionalist folklore, with certain structuralist nuances sometimes misplaced; There we can add the role of the Catholic Church and Protestantism that was turning Puno as a territory of struggle of adherents, that in practice Catholicism after having a preponderant role in the transformation of the region especially with the Institute of Pastoral Andina (IPA), where he put and knew how to face the great problems of the region in the line of liberation theology had positive and encouraging results in the logic of critical thinking, today has renounced and vanished with the extinction of its organizations and their publications. In economics, that is to say, we have been choked by savage capitalism via the neoliberalism expressed in our ways of doing social sciences in the altiplano.

In this scenario is evident the mercantilization and control of thought and surveillance via the media where the world is imposed on the world the American way of life. In the university field, such global hegemony has had various forms of ideological and theoretical legitimation according to the disciplines in question. Its proponents have appealed both to the monetarist postulates of neoclassical economics and to the postmodern discourses of "difference", "identity" and "linguistic turn", not 
forgetting either "poststructuralism and postmarxism, among many other academic accounts . "(Kohan, 2005).

We want to be clear that when we refer to the social sciences in Puno, we are not strictly referring to the Faculty of Social Sciences of the National University of the Altiplano, where it houses the schools of Sociology, Anthropology, Social Communication Sciences, Tourism, Art and the Department of Humanities. In fact, it has a responsibility to inform society about its role in building knowledge and its contribution to the development of Puno, the country and the world. Some who pass through these cloisters of the alma mater of the Puneños, from our experience, where we still see pain, wounds, scars, traps, among other evils; In the same way we identify other ways of facing the life that rises and arises from the deepest of the ancestral wisdom that "modern" social science still can not interpret and transform.

However, critical thinking from the social sciences in the highlands means facing and embodying social historical processes carried on in this context where the academy and the school mutilated other forms of wisdom and action relegating it as insignificant and irrelevant to the different disciplines, Without presage the importance they currently have in the work of critical theory. On this situation, Mariátegui maintained: "national education, therefore, does not have a national spirit: it has rather a colonial spirit and colonizer, when in its programs of public instruction the State refers to Indians, it does not refer to them Like Peruvians equal to all the others. He considers them as an inferior race "(Mariátegui 1928, 106), although the scenarios have changed, but still the problems remain valid and unresolved, for the Quechua, Aymara and Amazonian peoples.

Recreation of critical thinking from the Andean emancipatory spaces

Critical thinking as a historical process of the construction of knowledge transits through various scenarios of the work of the social sciences. It may be pertinent to reemphasize Wallerstein's works, "Opening the Social Sciences," which is a compilation of articles in which various representatives of the social sciences present to us the crisis of the social sciences, which in its development will be questioned, Not only in the periphery but also in its own contexts and one of the main figures of the Staatswissenschaften, it was Max Weber who took the initiative to found the German Sociological Society, which later became one of the most influential of Sociology, which in many contexts such as the high plateau was tied from the academy to this type of sociology, or in some cases stuck to the positivist thinking of Durkheim and Marx. Today it is difficult for them to unchain this anchor, whose forms of expression and expression are those that face the social movements and the original populations, because through the filters of analysis and cataloging, they are quickly disqualified or extinguished.

There are several authors that highlight the initiators and representatives of critical thinking; For the Westerners there should be no initiator in Latin America, least of all in the altiplano. However, for our case, they have to do with the political thinking of Felipe Guaman Poma de Ayala, in his work: "New Coronica and Good Government" (1615), which the social sciences have minimized as a strictly historical issue and Archaeological From our point of view he is one of the initiators of critical thinking, as many authors like Walter Mignolo, Enrique Dussel, among others.

From the perspective of the Eurocentric tradition, the first systematization of critical thinking is identified with Karl Marx and Frederick Engels, who underpin innovative approaches from philosophy to convert it into a theoretical source to promote social transformation, since they were the backbone of their proposal The scientific diagnosis of the capitalist mode of production and came to the conclusion of identifying it as the cause of the evils that afflict modern society and the realization that only the revolutionary struggle allows for a truly humanist social project, the communist mode of production. Characters such as Antonio Gramsci, Vladimir Ilich Lenin, Rosa Luxemburgo, León Trosky, etc. continued in this tradition. (Saldino 2012, 4). These thinkers have influenced the work of the social sciences in Peru decontextualized to the present.

In the same way, the second moment of the exercise of critical thinking was developed by a community of intellectuals who in the first decades of the 20th century founded the Institute of Social Research in Germany: Inaugurated in 1924 in the city of Francfurt, among them Theodor W. Adorno, Walter Benjamin, Erich Fromm, Max Horkheimer, Otto Kirchheimer, Leo Löwenthal, Hebert Marcuse, Franz Leopold Neumann, who developed their approaches with the name of Critical Theory of Society (TCS), oriented to the revision and renewal of Marxist approaches from an interdisciplinary perspective, distancing itself from Soviet Marxism and that in the decade of the sixties of the twentieth century, this Institute, linked to the University of Frankfurt, became popular With the name of School of Francfurt.

Our stay in Europe obliged us to have a reading of the emancipatory thoughts and reflections and to be able to identify some disciples of the School of Francfort through the classes of our teachers like: Helio Gallardo, Antonio Wolkmer, Boaventura de Sousa Santos, David Sanchez, Juan Carlos Monedero, Alejandro Medici, Franz Hinkelamerth, Wim Diercksens, François Houtuart, among others, but directed by the master Joaquin Herrera, 
may he rest in peace. From his reflections we identify: Karl-Otto Appel, Jünger Habermas, Axel Honneth, Alfred Schmidt, Samir Amin, Pierre Bourdieu, Noam Chomsky, Immanuel Wallerstein, etc., who incited us to exercise the search and struggles of others life forms. To that in the undergraduate classes between the nineties of the last century we had no reference, which confirms that we were disconnected and disconnected from the academic debate from the Peruvian highlands.

As a result of our passage through the cloisters of the University of Pablo de Olavide in Seville, we understand that it was possible to visualize the pain from the wounds and scars of Latin America, to which Galeano would say open veins; We were quickly related to the thought of José Carlos Mariátegui and as one of the most lucid expressions of Latin American critical thinking. We were proud because we were studying the doctorate in the human rights classroom that bore the name of the great amauta. In short, Mariátegui is one of the most outstanding representatives of critical thinking. In the same way, in each critical reading, the veils that concealed the claims of the peoples of deep Peru opened up to us, assuming, "it is not possible to develop dual, reflexive, invaded, dependent societies of metropolitan society, as societies Alienated whose point of political, economic and cultural decision is outside of it "(Freire 1969, 170).

These forms of action in the work of the social sciences, we would have the eyes to see otherwise the Latin American reality, and we could only understand the reflections that placed us on the table Walter Mignolo, Enrique Dussel, Guillermo Bonfil, Eduardo Restrepo, Arturo Escobar, Fals Borda, Paulo Freire, Chico Méndez, so we can list and mention others that today are references that lead us to understand the importance of critical thinking in the social sciences.

In Peru, it is necessary to point out that with the independence of 1821 colonialism was not eliminated or ended, "because it followed the internal colonial structure. Because the groups that have held power since then have never renounced the western civilization project nor have they overcome the distorted view of the country, which is consubstantial with the colonizer's point of view "(Bonfil 2001, 11). Who from the social sciences, always fell into the temptation of the murderer of historical memory and the dignity of human. A clear example is the political violence undertaken by Sendero Luminoso (SL) and the Tupac Amaru Revolutionary Movement (MRTA) in the 1980s, whose leaders and leaders wanted to apply orthodox Eurocentric ideologies, totally decontextualized to the Andes, Altiplano, despite being painful it was frozen and rejected. When this happens it becomes sterile, trasnochado and farce, it does not illustrate Pablo
Gonzales Casanova, referring to his book, "is written for those who stay in the slogans and pompous words of orthodox and dogmatic Marxism, renouncing the great traditions That Marxism itself has high-level scientific research, which has always complemented and accompanied militant research "(Gonzales 1970, 3). It is not that Marxism is good or bad, but that these ideologies have to be kneaded and chewed from the everyday social movements and struggles of the original peoples.

Another of the important representatives of critical thinking is Anibal Quijano, a San Marquino sociologist, who today has become an important referent, the colonizers exercised various operations that account for the conditions that led to the "configuration of a new universe of relationships Intersubjectives of domination between Europe and the European and other regions and populations of the world, to which they were being attributed, in the same process, new geocultural identities "(Quijano 2000, 246). Quijano was in several occasions in Puno, but since it was not yet considered, it was not even noticed by the sociologists themselves, even their sociological contributions from Latin America were not taken into account.

From the theology one of the international references of the critical thinking is Gustavo Gutierrez, that is to say, from the theology of the liberation has contributed to face and visibilizar the victims of the system. No need to victimize anyone, but to repair or not to hide that in our societies there are injustices of many types, which we can not be naive or silent, but fight for the justice and ethical indignation that our peoples face today.

Now, from our perspective, the representatives of critical thinking in the Altiplano (Puno), are those of the Orkapata group, in that line is important the thought of Jose Antonio Encinas, who from his monumental work "A test of a new school in Peru" Influenced the work of the social sciences, not only in Puno, but also in Latin America. In spite of its origin with other mestizos of faced the educational problematic of Peru from the altiplano.

\section{The importance of critical thinking from the altiplano a commitment to decolonization of knowledge}

For the social sciences anchored in eurocentric positivism it is still complex to decipher the development and importance of critical thinking from the highlands, the categories recreated by the disciplines such as coloniality, postcoloniality, postmodernity and decolonization are not being contextualized according to everyday life of the peoples of the periphery, but from the experience of the peoples settled around the Titicaca lakes, little or nothing has to do with the assimilation of conceptual categories, because they often become untranslatable. In spite of everything there is a sufficient bibliography on Puno, 
where we can visualize the ethnographic description of other ways of thinking of Quechuas, Aymaras, Uros, and Amazonian; When we speak of Puno we can not reduce only to strictly geographical issues, but it is necessary to underline the importance of thinking from the highlands for Peru and for Latin America.

The process of decolonization is to recognize the importance of other forms of wisdom existing in diverse and heterogeneous contexts, although they are not cataloged of knowledge by the monistic and hegemonic academy, which has already been surpassed by thinkers, such as:

The differences associated with different positions, that is to say, goods, practices and above all manners, function in each society in the manner of the constitutive differences of symbolic systems, such as the set of phenomena of a language or the whole Distinctive features and differential deviations that are constitutive of a mythical system, ie as distinctive signs (Bourdieu 1997, 20).

In this line we can identify José Gabriel Condorcanqui, that is to say Tupac Amaru, as the initiators of the critical thinking of the Altiplano, for his ways of thinking were dismembered, Micaela Basitas, "the rebels were also based on the idea of" bad government " That people could take direct action against corrupt or disruptive authorities "(Walker 2015, 62). In 1781 Julian Apaza, assumed the name of Tupak Katari, along with his brothers Tomas Katari, Dámaso, and Nicolas, assumed the leadership of the insurrection, who were assassinated by their ways of thinking and acting. "Tupaq Katari's rebellion is perhaps one of the least documented in the" eighteenth-century Andean "insurgency era" (Thomson, 2006, xi). This period has an important meaning for the social sciences in the Altiplano, which from the perspective of cognitive injustice has veiled and mutilated. The colonial backwardness from the academy shielded thoughts and actions of cognitive injustice, that is to say we live and witness to the epistemicide of the wisdom of the Quechua, Aymara and Amazonian peoples, whose consequences we are facing today.

We already mentioned the importance of the thought of Manuel Z. Camacho in the work of indigenous education, had an important impact in Peru. The demand and the struggle for education for the Aymaras, Quechuas and Amazonian have cost lives, for that reason has generated diverse confrontations with the State and the Church. Faced with this situation and in spite of complex adversities, various organizations had been organized and constituted and one of the most important organizations was the "Orkopata Group" formed by the Puneños who were witnesses of the abuses of the mistis in the different cities where they settled The gamonales. A large variety of publications appeared, with "indigenist" and other leftist tendencies. These had Eurocentric content, which did not yet portend language, territory, political, social, environmental and cultural. It was led by the group by Gamaliel Churata, who was his pseudonym, whose real name was Arturo Peralta Miranda, today is of interest to academics and intellectuals in the world his works and his thought, Churata, in this tour, perhaps the Difficult "," turns out to be the abolition of the logical hierarchies that structure critical thinking, necessary operation if we want to create enough space to hear the other voice of Latin American literature "(Badini 2013, 29). Their ideals and thoughts are valid and it is a pending subject to face, not only from the perspective of literature, but from the social sciences.

The importance of Encinas' thought for the social sciences "was incisive, in the scientific order, no research had been carried out to know the different problems of social, economic, and legal order in relation to the Indian. The same official history of Peru was in the hands of neophytes, while abroad, German, English, French sociologists studied the social and economic organization of the Indians thoroughly "(Encinas, 2007, 110). He incited the change to the school, so that its objectives respond to social equality, that today we still face the same problems.

In 1967 Bourricaud had already published the text "Changes in Puno" that should be a compulsory reading to understand the processes of social change from Puno. Thus we can identify other works such as José Luis Renique: "The Battle for Puno" (2004), who traces the historical process between 1866 and 1995, is important because it identifies and recognizes the role assumed by leaders such as: José Antonio Chamabilla in The area of Mazocruz, now part of the province of El Collao. On the other hand, he will thank Marcelino Pachari and Porfirio Suni, two Quechua leaders.

In the north of Puno, specifically in the Aymara province of Huancané, they sacrificed their lives for the respect and dignity of the Tawantinsuyo peoples, such as: Carlos Condorena Yujra (1891-1956) (Ayala 2006); Mariano Luque Corimayhua, who founded a clandestine school in Aña-Aña-Huancho, was assassinated and anchored to the river after leaving Huancané prison on 10 January 1924. Mariano Pacco Mamani (1890-1923) was instructed by amauta José Carlos Mariátegui, was a leader of the peasant movement of 1923, was captured along with other leaders, after three days of torture was taken to the river at 2 am on December 17, 1923 was also anchored to the river Huancané. Rita Puma Justo born on January 2, 1900, the story tells that she was cruelly tortured and then hanged in one of the eucalyptus trees in Moho Square, although it is true that "she is a woman without a biography" (Ayala 2005), As many leaders and leaders 
Quechuas, Aymaras, Amazonian and some mestizos friends of the "Indians" do not have monuments nor official histories. In this perspective (Alanoca 2007, 19):

The commitment to language, education, human rights, are processes of struggle that involve collective sacrifices. The thought of refounding Peru, which Condorena assumed and dedicated to his life, in the last century, are pending tasks for the social actors of today. Wancho Lima expresses the living answer of the exclusion and of the crimes that were committed. Now, on those wounds and scars you have to rebuild the country.

To this day, the social sciences have called them "radicals" and "conflictive" to legitimize a single way of thinking and acting, creating a catacomb of categories untranslatable into the Andean languages, such as "interculturality", "governability" Community relations "," community management ", among others. Therefore, the presence of critical thinking in the Peruvian highlands is undeniable, to which the disciplines of the social sciences should focus their attention and analysis on the contextualization of theoretical perspectives and their methodologies, so that their interpretations are pertinent and Appropriate.

On the other hand, Puno can not be understood without intellectual reference. Puneños that put in the table of the critical thought like M. Ignacio Frisancho (1947, 79), we had access to one of its writings, who maintained the following thing:

Peru is a heterogeneous country, under all aspects of its life, especially in the economic and social. Coast mountain and mountain; North, South, Central and East, these fractions of the homeland differ significantly in their ideology, customs, language, economics and other forms of social entities. Add to this that just a quarter of a century ago that wide communication has begun; Because each region has lived in isolation in relation to the others, so that properly speaking we do not form a perfect nationality, lacking the essential: the link of the connection.

From the perspective of critical thinking, it is a pending reading, and it should be mandatory in the social sciences in Puno, because the problems that have been covered with soft, immeasurable veils and curtains from school, college, university, That is, legitimized by the academy via the television media that capitalism has established for the people, that today we weigh a culture of savage consumerism.

Several sectors of the public administration in Puno has not found compass nor much less the north in recent years. There are several pending subjects in Puno for the social sciences, which we have to put our service and develop research to help solve problems, among which are still outstanding are the events of 2004 in Ilave
(Alanoca, 2013) and the aymarazo of 2011 Beyond fanaticisms of andinocentrism, it requires an approach from the critical perspective, not a simplistic ethnography of counting of facts, but of facing to compensate neófitos errors that discredited to the towns, mainly Aymara.

Our strategies of analysis and our theoretical referents have to be rethought if we want a plural, diverse and wise Puno. Demands and struggles should never be more spontaneous than blackmail and arrogance under the umbrella of Andean identity tends to legitimize exclusive thoughts of frustration and tragedy of peoples that history has placed us for example three Regional presidents who have not been able to consolidate a solid and political proposal of the claim of the Puno, from Romeo Paca, David Jimenez, Hernan Fuentes, Mauricio Rodríguez and now Juan Luque, perhaps a positive result is to have raised the Regional Curricular Project PCR), which many of us just stayed in and celebrate, gave us the time to put into action, of course because it still had and has many gaps, which political decision makers themselves have not understood and much less became interested in.

In this context of the development of critical thinking, it is important to clarify the motivations and tendencies that are present today in the work of the social sciences in the world of academia, the ideas of Boaventura de Sousa Santos (2005), Joaquin Herrera, Eduardo Galeano, José Carlos Mariátegui, José Antonio Encinas, Tupak Katari, and José Antonio Chambilla, among others, have taught us to understand that the epistemology of the South in a sociology of emergencies is not only a rhetorical question, Cognitive, that on it we must develop the critical thinking of the social sciences in highland.

In recent years, the other forms of knowledge that are generated not from the cloisters of the academy or of the intelligentsia are being emphasized, but from the denied spaces, such as the peasant communities, to which the social sciences and social policies Undertaken in Puno, have been abandoned, not only by local, regional and national governments; Are also abandoned by the academy, that is, it has little interest in the disciplines especially of researchers. The reforms introduced in the system of communal organization had a destructive repercussion of other forms of ancestral community organization of ethical and moral components. But we must note that ancestral wisdom is being disrupted from the depths until in some contexts it is being made up by savage capitalism and the colonial backwardness and it is only a fallacy, especially in the history of Puno.

Critical thinking in this context is the construction of an emancipatory thinking from everyday life, where the population has learned to recreate strategies to solve social problems; Which the market has excluded and incorporated to be worthy consumers of technology, 
fashion priority in spite of the generational disconnection where the young people have lost their memory or in any case have been formatted by television and the culture of consumption. On the other hand, it is important to emphasize that "in recent decades, various Latin American indigenous organizations and certain intellectual groups linked to them have marked the differential ethnic and cultural fact as a positive advantage for all these peoples, struggling to strengthen in the context Of the national society "(Marchena 2011, 73).

The large transnational corporations have recruited young people to be the allies to legitimize the extractivism that is affecting the experience of the peoples; To this end it has created a series of conceptual categories from the disciplines, which on it raises the curricular contents of the social sciences in Peru. Moreover, the background of the thematic contents is defined by the World Bank or the Inter-American Development Bank, they define the topics to be investigated, including legitimizing academic discourse based on academic orthodoxy and co-opting leaders of Social and indigenous organizations, although this still sounds or has a contemptuous content. These agencies that we already know for those who play and what interests defend - define what is investigated; How it is investigated; Who, when and where, and for what; And above all, what are the acceptable results of the research. It may sound illogical, when (Boron, 2005, 9) argues:

The research agenda of the Social Sciences in Latin America, and fundamentally of Sociology, is not only controlled by funding agencies - increasingly scarce, concentrated, and with very strong ideological control but also by the editorial committees of The American journals and, to a lesser extent, European journals, who determine whether an article by a Latin American is pertinent to its object of study and correct in its theoretical and methodological formulation.

In this scenario, "the social sciences can not fall into the legitimacy of an exclusive academy, despite the inequalities between universities in the North and universities in the South, they are enormously aggravated" (Santos, 2005). Consequently, it is becoming increasingly difficult to create critical thinking within academia, because the formation of the different disciplines in the cloisters of the academy apart from being decontextualized, some are out of date in their approaches, methodologies and strategies. It is more critical when some teachers legitimize the mediocrity of vocational training of young people, that the great majority are of Aymara and Quechua origin in the case of the universities of Puno. It has become in some cases a kind of repetitive monologation that only allows us to accept and assimilate what we have, little or nothing challenging, in some cases our formations are useless and sterile in the process of building emancipatory knowledge.

Despite tragedies and veils of exclusion, discrimination and hatred, from the highlands, in our Peruvian case, from the foothills of the Andes, nor the inclemencies of nature has stopped them or contained, such as droughts, frost and storms, There arise bold and daring thoughts that are conquering Peru, which the social sciences from their plots of disciplines enclaustrates or stigmatizes, which Matos Mar called "popular overflow" we refer to the waves of migration that was happening, a case Illustrative is that of the Unicachi in Lima; Large number of populations settled today in Arequipa, Tacna, Chile, Argentina, among other parts of the world. They are those who from their daily lives challenge the spaces of political power and knowledge.

Today Peru is increasingly hit by insecurity and corruption, in many cities it becomes uncontrollable, as the case of Lima, despite the fact that there are all the institutions linked to the security issue, with the centers High-level training, with the supposedly imminent political class, but in practice it seems incapable of coping with this complex situation of insecurity, conflict, corruption, drug addiction, drug trafficking, etc. But, we find communities in the highlands, where there is neither a police force, nor the presence of state operators, nor social programs, however, from their daily experience, between their ethical and moral principles of behavior and wisdom build Hopes of collective life, interwoven by the burning pain of exclusion and discrimination. Where its historical memory has been formatted by the school of the European colonizing model; Has disconnected and disconnected from the community under decontextualized content.

In the Peruvian highlands, in particular Puno, despite the colonial cataclysm, the wisdom remains the best expression of the struggle for dignity. Independence was Creole and mestizo, where the struggle of the jaqi or rune was never taken into account by official history; From the social and indigenous movements recreated their demands with wisdom with a critical sense, not under the anchorages of Eurocentric theories, but was built from the everyday. In sum, the presence of thought is evident. Therefore, it is important to transit and construct other tracks of critical thinking from the altiplano to the country of all the blood.

\section{BY WAY OF CONCLUSIONS}

The economic and social crisis in the world is evident, so the crisis of the social sciences is also visible, because the problems faced by people in Latin America and specifically in Peru, in this context we can not look for recipes and solutions decontextualized to this reality. In 
the world of academia, the crisis of the social sciences since Europe has been addressed in the last century, which from Latin America many academics, intellectuals and leaders have been facing and struggling in the search for other forms of thought, Social sciences has not taken into account to address the major problems facing today's large cities and peoples in the world.

In the Peruvian highlands, specifically in Puno, other forms of thought have been developed that defied the monocultural and homogeneous thinking system, from the ancestral leaders, who by their ways of thinking and acting were annihilated. However, from the point of view and daily life, some of the intellectuals and leaders in Pune faced and incarnated the importance of critical thinking, which today are pending subjects to be developed.

These forms and actions of emancipatory thinking can not continue to be considered as common senses, because in the face of so many situations of adversity are recreated and are alternative ingredients of decolonization, they have to be developed from education, understanding this as a premise of transformation Of reality for it must leave the shell conservative decontextualized.

\section{REFERENCES}

[1] Alanoca, Vicente. 2011. Movimiento indígena aymara.Una búsqueda y expresión de derechos humanos.Saarbrücken: EAE.

[2] Alanoca, Vicente. 2012. El buen vivir en la cultura aymara. Recreando esperanzas y alternativas desde las heridas y cicatrices.Saarbrücken: EAE.

[3] Alanoca, Vicente. 2007. "La historia aun no contada".En Calibdo Abierto 15. Junio. p.19.

[4] Ayala, José Luis. 2006. El presidente Carlos Condorena Yujara. Lima: San Marcos.

[5] Ayala, José Luis. 2005. Celebración cósmica de Rita Puma. Lima: San Marcos.

[6] Bourricaud, François. 1967. Cambios en Puno. Lima: Instituto de Estudios Peruanos.

[7] Bonfil, Guillermo. 2001. México profundo. México: Conaculta.

[8] Boron, Atilio. A. 2005."Las ciencias sociales en la era neoliberal: entre la academia y el pensamiento crítico".En Conferencia Magistral pronunciada en el XXV Congreso ALAS (Asociación Latinoamericana de Sociología), Porto Alegre, Brasil.

[9] Bourdieu, Pierre. 1997. Razones prácticas. Sobre la teoría de la acción. Barcelona: Anagrama.

[10] Encinas, José. 2007. Un ensayo de escuela nueva en el Perú. Puno: Facultad de Ciencias Jurídicas y Políticas. Universidad Nacional del Altiplano.

[11]Facione, Peter. A. 2007."Pensamiento crítico: ¿qué es y porqué es tan importante?” Insight assessment,
California

Academic

Press.

http://www.eduteka.org/PensamientoCriticoFacione. php

[12]Foucault, Michel. 1972. La arqueología del saber. Madrid: Editorial Siglo XXI.

[13]Fairlie, Alan. 2016. Ed. El Perú visto desde las ciencias sociales. Lima: PUCP.

[14]Freire, Paulo. 1969. Pedagogía del oprimido. Madrid: Siglo XXI.

[15] Frisancho, Manuel. 1946. Los tiranos no nacen sino que los hacen. Buenos Aires: Instituto del Libro.

[16]Peralta, Arturo. 2013. La resurrección de los muertos. Puno: Universidad Nacional del Altiplano. Edición y estudio introductorio, Badini, Ricardo.

[17] Gonzales, Pablo.1970. Sociología de la explotación. México: Siglo XXI.

[18] Marchena, Juan. 2011. Oír la voz de los cerros. Los pueblos andinos en su lucha por la educación. Puno: Universidad Nacional del Altiplano.

[19] Mariátegui, José Carlos. 1928. 7 ensayos de interpretación de la realidad peruana. Lima: Amauta.

[20] Morin, Edgar. 2001. Introducción al pensamiento complejo. Barcelona: Gedisa.

[21]Letamendía, Francisco. 2011. El indigenismo en Suramérica: los aymaras del altiplano. Madrid: Fundamentos.

[22] Harris, Marvin. 2000. Teorías sobre la cultura en la era posmoderna. Barcelona: Crítica.

[23] Husserl, Edmund. 2008. Las crisis de las ciencias europeas y la fenomenología trascendental. Buenos Aires: Prometeo.

[24] Kohan, Néstor. 2005. Fetichismo y hegemonía en tiempos de rebelión. La Habana: Ciencias Sociales.

[25] Portocarrero, Gonzalo. 2015. La urgencia por decir “nosotros". Lima: PUCP.

[26] Portocarrero, Gonzalo.2013. Sombras coloniales y globalización en el Perú de hoy. Lima: IEP.

[27] Quijano, Anibal. 2000. "Colonialidad del poder, eurocentrismo y América Latina”.EnLa colonialidad del saber: eurocentrismo y ciencias sociales. Perspectivas Latinoamericanas.p. 246. Buenos Aires: CLACSO, Consejo Latinoamericano de Ciencias Sociales.

[28] Renique, José Luis. 2004. La batalla por Puno. Lima: Instituto de Estudios Peruanos.

[29] Santos, Boaventura de Sousa. 2010. Descolonizar el saber, reinventar el poder. Montivideo: Trilce.

[30] Santos, Boaventura de Sousa. 2005. La universidad en el siglo XXI. Para una reforma democrática y emancipadora de la universidad. Buenos Aires: LPP/Miño y Dávila Edito. 
[31] Saldino, Alberto. 2012. Pensamiento crítico. México: Universidad Autónoma de México.

[32] Thomson, Sinclair. 2006. Cuando sólo reinasen los indios. La Paz: Muela del Diablo

[33] Walker, Charles. 2015. La rebelión de Tupac Amaru. Lima: Instituto de Estudios Peruanos.

[34] Wallerstein, Inmanuel. 2006. Abrir las ciencias sociales. Madrid: Siglo XXI.

[35] Wallerstein, Inmanuel. 2007. Geopolítica y geocultura. Ensayos sobre el moderno sistema mundial. Barcelona: Kairós. 